\title{
水蓄放熱床をもつ太陽熱床暖房システムの性能に及ぼす建物構成要素の 影響に関する研究 \\ STUDY ON THE EFFECT OF BUILDING AND SYSTEM FACTORS ON THE THERMAL PERFORMANCE OF THE SOLAR HEATING SYSTEM WITH WATER FLOOR
}

\author{
咸 哲 俊*, 須 永修通**, 堀 祐 治*** \\ Zhejun XIAN, Nobuyuki SUNAGA and Yuji HORI
}

\begin{abstract}
The purpose of this study is to clarify the effect of building and system factors on the thermal performance of the solar floor heating system with Water Floor (water heat-storage floor) by simulation analysis. The examined building and system factors are the heat capacity of Water Floor, the material of heat-storage floor, the thickness of thermal insulation of building envelope, climate etc. From the results, it was found that Water Floor can raise generally $20 \%$ of comfortable time rate and is effective to raise thermal environment level, comparing to the concrete floor and plywood floor, and so on.
\end{abstract}

Keywords: water floor, thermal storage, solar heating, floor heating, building and system factor, simulation 水蓄放熱床、太陽エネルギー、床暖房、建物構成要素、シミュレーション

\section{1. はじめに}

建築の室内環境調整において、有効に自然エネルギーを利用する には断熱性などの建物の性能を高めるとともに適切な蓄熱量を付加 することが重要である。一方、室内快適性向上と高龄者などのヒー トショックをなくすためには住宅内の温度差を小さくすることも求 められている。これらの要求から、筆者らは自然エネルギー利用と 熱的バリアーフリー空閒の形成を目指して提案された太陽エネル ギー利用水蓄放熱床暖房システムについて研究を行ってきた。

既報 1)では、実大実験住宅を用いた二冬にわたる実験結果から室 内温熱裳境の形成状況や水蓄放熱床の蓄放熱性能などについて検討 を行った。その結果、太陽熱だけで冬季の室温が $15{ }^{\circ} \mathrm{C} \sim 25^{\circ} \mathrm{C}$ に維 持されるなど本システムの省エネルギー効果および快適性が示され た。また、建物構成要素の影響については、床下ダクトを設置する ことにより日中の水蓄放熱床の集熱量に対する蓄熱量の割合を $10 \%$ 程度増やすことができるなどの結果を得た。しかし、その他多くの 建物構成要素の影響およびその程度についてはまだ明らかになって いない。

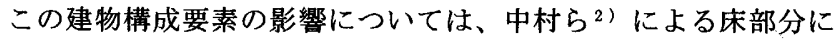
蓄熱体がない太陽熱空気集熱床暖房住宅における集熱部、建物方位 などの影響に関する検討がある。また、渡辺ら ${ }^{3)}$ は計算により蓄 熱部位としてべた基礎より床部分の方が適していることを指摘し
た。しかし、床部分に蓄熱体がある場合における各部分の影響につ いて検討した研究例は見当たらない。

そこで、本研究では、建物や水蓄放熱床の断熱性や熱容量が システムの性能にどのように影響するかを明らかにすることを 目的として、シミュレーションにより検討した。

\section{2. 対象モデル住宅およびシステムの概要}

計算対象は、東京都八王子市南大沢の都立大学のキャンパス内に 建設された在来軸組工法の木造平屋建、床面積 $66.25 \mathrm{~m}^{2}$ 実大実験 住宅とした。屋根と外壁は高性能断熱材 $100 \mathrm{~mm}\left(\lambda=0.02 \mathrm{~W} / \mathrm{m}^{2} \cdot \mathrm{K}\right)$ で、基礎、土間床コンクリートは発泡ポリスチレン $100 \mathrm{~mm}$ で断熱さ れている。図 1 に断面図、図 2 に平面図を示す。

実験住宅の屋根面は、アモルファスタイプの太陽光発電パネルと 一体となった金属板莫屋根と高温集熱用ガラス屋根とで構成され ている。冬の集熱時、棟部分の集熱空気温度が設定温度(ここ では $30{ }^{\circ} \mathrm{C}$ ）に到達したら床下空間に設置したハンドリングボッ クス内のファンが作動し、外気取り込みを始める。軒先から取 り込まれた外気はまず太陽電池パネルを取り付けた鋼板の裹側を通 りながら予熱される。その後、集熱ガラス部分で高温に加熱され、 床下ダクトに運ばれる。床下ダクトに運ばれた外気は床下空間に吹
* 東京都立大学院工学研究学科建築学専攻 大学院生. I修

** 東京都立大学院工学研究学科建築学専攻 助教授 - 工博

*** 建築研究所 工博
Graduate Student, Dept. of Architecture, Faculty of Engineering, Tokyo Metropolitan Univ., M. Eng.

Assoc. Prof., Dept. of Architecture, Faculty of Engineering, Tokyo Metropolitan Univ., Dr. Eng.

Building Research Institute, Dr. Eng. 


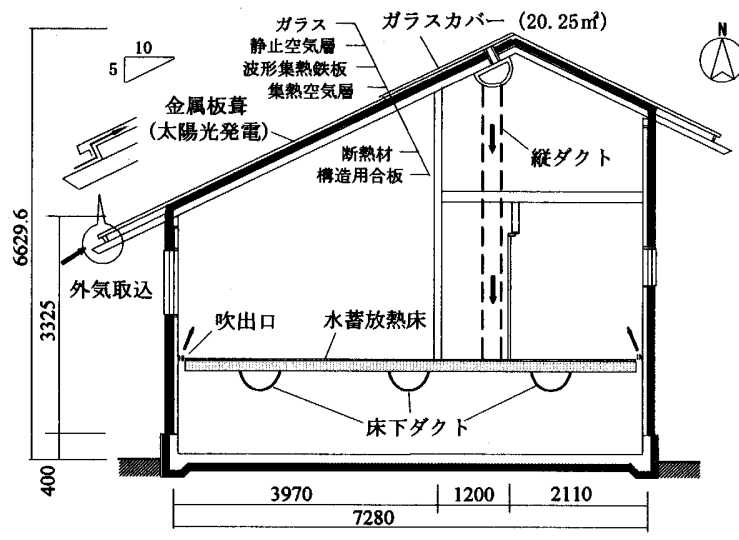

図 1 断面図

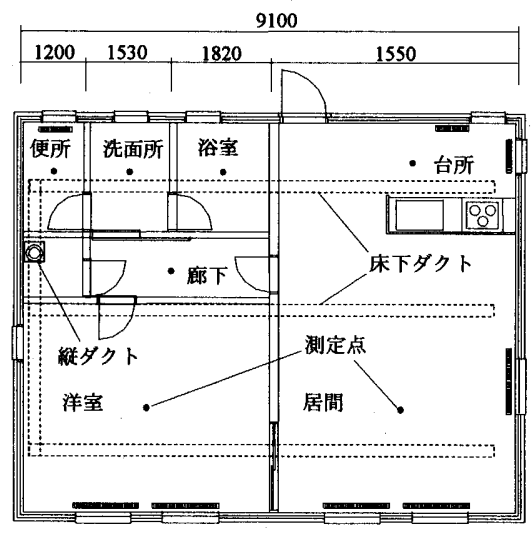

图 2 平面図
表 1 外壁体構成

\begin{tabular}{|c|c|c|}
\hline 外気側 & $\lambda(\mathrm{W} / \mathrm{mK})$ & 厚さ \\
\hline 鋼板 & 53 & $2 \mathrm{~mm}$ \\
\hline 空気層 & \multicolumn{2}{|c|}{$0.09\left(\mathrm{n}^{2} \mathrm{~K} / \mathrm{w}\right)$} \\
\hline 合板 & 0.18 & $9 \mathrm{~mm}$ \\
\hline $\begin{array}{l}\text { 高性能フェノール } \\
\text { フォーム }\end{array}$ & 0.02 & $100 \mathrm{~mm}$ \\
\hline 石高ボード & 0.17 & $12 \mathrm{~mm}$ \\
\hline
\end{tabular}

\section{表 2 土間床構成}

\begin{tabular}{c|c|c}
\hline \multicolumn{1}{c|}{ 朱下空間側 } & $\lambda(W / \mathrm{mK})$ & 厚さ \\
\hline コンクリート & 1.6 & $150 \mathrm{~mm}$ \\
\hline $\begin{array}{c}\text { 発泡ポリスチレン } \\
\text { フォーム }\end{array}$ & 0.034 & $100 \mathrm{~mm}$ \\
\hline \multicolumn{1}{|c|}{} & 1.5 & $3 \mathrm{~m}$ \\
\hline
\end{tabular}

表 3 密とドアの熱貫流率

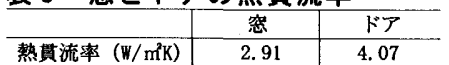

き出され、その後各室の周囲に設けられた吹き出し口から室内に開 放されるが、その間、床下ダクトでは水蓄熱体に、また床下空間で は土間床コンクリートへの蓄熱が行われる。なお、太陽光発電シ ステムは系統連携されている。

\section{3. 計算方法概要}

本研究ではシステムの構成要素の影響を検討することを目的にす るため、床上側の居住域と床下空間をそれぞれ一つの部屋として計 算を行った。計算プログラムは宇田川 ${ }^{4)}$ の天井裏空間を給気チャ ンバとした場合の二室計算モデルプログラムを参考に作成した。壁 体の非定常熱伝導の計算は後退差分を使用した。室内表面の総合 熱伝達率は $9.3 \mathrm{~W} / \mathrm{m}^{2} \cdot \mathrm{K}$ とし、その中で放射熱伝達と対流熱伝達割 合は $55 \%$ と $45 \%$ にした。床下空間の天井と土間床スラブ表面の熱伝 達率は、熱流方向が上向の時は $11.63 \mathrm{~W} / \mathrm{m}^{2} \cdot \mathrm{K}$ とし、下向の時は $6.98 \mathrm{~W} /$ $\mathrm{m}^{2} \cdot \mathrm{K}$ とした ${ }^{5)}$ 。室外表面総合熱伝達率は $23.0 \mathrm{~W} / \mathrm{m}^{2} \cdot \mathrm{K}$ と設定した。 各表面の㬏射率は 0.9 とし、室内表面での相互放射熱伝達は表面間 の形態係数、輻射熱交換係数などから計算した。換気による熱損 失量の計算においては、日中の集熱時間帯の換気量は集熱風量 と同じとして、また、集熱時以外は換気回数を用いて計算を 行った。計算時間間隔は 1 時間、気象データはアメダスの標準年気 象データを使用した。

\section{1 水蓄放熱床モデル}

システム性能に重要な影響を与える水堖放熱床については、図 3 のようなモデルで計算した。実大実験住宅の水蓄放熱床は、厚さ $0.125 \mathrm{~mm}$ の多層ラミネート材の袋に水を入れたウォーターバッグ $(9 \mathrm{~cm}$ $\times 25 \mathrm{~cm} \times 2,7 \mathrm{~m})$ を床の根太間に設置したものであるが、太陽熱集熱 空気により一部を加熱しても水の自然対流によりバッグ全体がほぼ 均一（加熱時であっても最大 $2{ }^{\circ} \mathrm{C}$ 以内）になることが実験 ${ }^{1}$ ) から 明らかになった。そこで本研究では、計算を簡略化するため、根 太がなく、床全面に一つの水蓄熱体が設置されていると仮定した。 水蓄熱体は厚さ $0.1 \mathrm{~mm}$ のビニール袋に熱が完全拡散する完全混合 水が入っているものとし、水蓄熱容量は実験住宅と同じく $3.6 \mathrm{kWh} / \mathrm{K}$ とした。集熱を行うときの完全混合水蓄熱体の熱平衡式 を式(1)に示す。

$\frac{\mathrm{RM}_{v}\left(\mathrm{~T}_{3}-\mathrm{T}_{3}{ }^{*}\right)}{\Delta \mathrm{t}}=\mathrm{A}_{上} \alpha_{上}\left(\mathrm{~T}_{2}-\mathrm{T}_{3}\right)+\mathrm{A}_{\mathrm{F}} \alpha_{\mathrm{F}}\left(\mathrm{T}_{4}-\mathrm{T}_{3}\right)+\mathrm{A}_{\text {集 }} \mathrm{K}_{\mathrm{c}}\left(\mathrm{T}_{\mathrm{co}}-\mathrm{T}_{3}\right) \quad$ 式 (1)

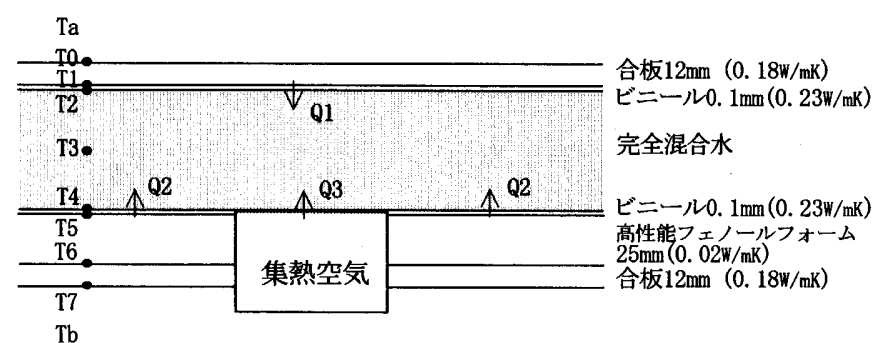

図 3 水蓄放熱床モデルの説明図

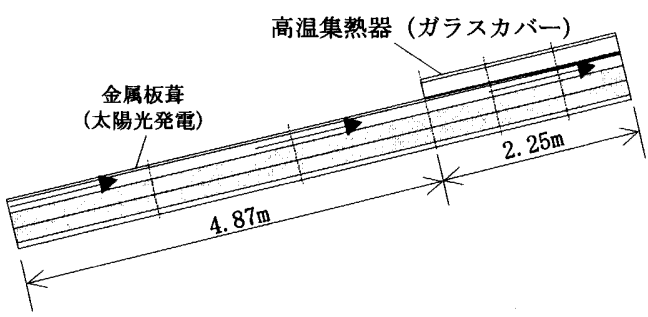

図 4 集熱器モデルの説明図

表 4 集熱器モデルの構成

金属板（太陽光発電）葺屋根構成

\begin{tabular}{|c|c|c|c|c|c|c|c|}
\hline & & & & & 17 & & \\
\hline 金属板 & & & & ガラス & $3 \mathrm{~mm}$ & 入射角の関数 & 0.84 \\
\hline & 厚さ & 日射吸収率 & 放射率 & 密閉空気層 & $50 \mathrm{~mm}$ & - & - \\
\hline 垔鉛鍍鉄板 & $0.6 \mathrm{~mm}$ & 0.7 & 0.7 & 選択吸収板 & $0.4 \mathrm{~mm}$ & 0.9 & 0.1 \\
\hline 集熱空気層 & $40 \mathrm{~mm}$ & 一 & 一 & 集熱空気層 & $40 \mathrm{~mm}$ & - & - \\
\hline 断熱材 & $100 \mathrm{~mm}$ & 一 & 二 & 断熱材 & $100 \mathrm{~mm}$ & 一 & - \\
\hline 合板 & $12 \mathrm{~mm}$ & 一 & 二 & 合板 & $12 \mathrm{~mm}$ & - & 一 \\
\hline
\end{tabular}

但し、RMw : 水蓄熱体熱容量、 $T_{m}$ : 現時点節点 $m$ の温度、 $T_{m}^{*}: \Delta t$ 時閒前の節点 $m$ の

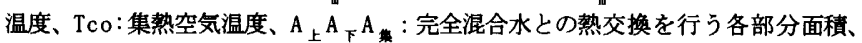
$\alpha_{上} \alpha_{下}$ : 自然対流による熱伝達率、 $\mathrm{K}_{\mathrm{c}}$ : 床下ダクト内集熱空気から完全混合水ま での熱貫流率、 $K_{\mathrm{n}}$ : 集熱を行わない時の床下ダクト空気から完全混合水までの 熱貫流率

集熱を行わない時は $\mathrm{T}_{\mathrm{co}}$ と $\mathrm{K}_{\mathrm{c}}$ の代わりに床下空気温度 $\mathrm{T}$ y と熱貫流 率 $\mathrm{K}_{\mathrm{nc}}$ を代入する。完全混合水とビニール間の熱交換は水の自然対 流のみによる熱交換とし、その熱伝達率は水平正方形平板の自然対 流伝達相関式から計算を行った。代表寸法は実験住宅の水蓄熱体幅 と同じ $25 \mathrm{~cm}$ として計算した。

床下ダクトは実験住宅と同じ断面面積を持つ 3 つのダクトがあ り、床下ダクト内の空気はダクト断面に均一に分布して流れると仮 定した。床下ダクト内の集熱空気と水蓄熱体の熱交換面積 $\left(6.9 \mathrm{~m}^{2}\right)$ は実験住宅と同じであり、対流熱伝達率はダクト内の空気速度 からユルダスの式により計算した。集熱を行うとき、床下ダクトは 完全断熱とし、集熱を行わない時の床下ダクト内空気温度は床下空 気温度と同じとした。 


\section{2 集熱器モデル}

実験住宅の集熱器は金属板莫屋根部分 $\left(44.54 \mathrm{~m}^{2}\right)$ とガラス高温 集熱部分 $\left(20.25 \mathrm{~m}^{2}\right)$ で構成されており、集熱風量は $648 \mathrm{~m}^{3} / \mathrm{h}$ で、傾斜 角は $26.6^{\circ}$ である（集熱量と屋根面日射量の関係は参考文献 1 を参 照)。集熱器計算モデルは実験住宅と同じ構成とし、説明図を図 4 、 集熱屋根の構成を表 4 に示す。集熱器計算は 1 時間間隔で、図のよ うに流れ方向に 6 分割して、6 接点目の空気温度を集熱器空気出口 温度とした。軒先から入った外気は厚さ $40 \mathrm{~mm}$ の空気層を均一に流 れながら集熱板などと熱交換を行う。集熱空気と集熱板の熱伝達率 は空気速度などからユルゲスの式により計算した。集熱器ガラス の日射垂直入射時の透過率は 0.86 、吸収率は 0.05 と設定した。 集熱空気から外気までの熱貫流率は $3.76 \mathrm{~W} / \mathrm{m}^{2} \mathrm{~K}$ 、室内までの熱 貫流率は $0.2 \mathrm{~W} / \mathrm{m}^{2} \mathrm{~K}$ である。なお、室外側の熱伝達率は $23.0 \mathrm{~W} / \mathrm{m}^{2}$ • $\mathrm{K}$ 、室内側の熱伝達率は $9.3 \mathrm{~W} / \mathrm{m}^{2} \cdot \mathrm{K}$ とした（室内側空気温度は定温 $20^{\circ} \mathrm{C}$ として計算)。

\section{3 地中温度の計算方法}

地中温度は深さ $3.0 \mathrm{~m}$ の温度を計算し、2 次元後退差分法で計算を 行った。計算を行う時の土裹の熱伝導率は $1.5 \mathrm{~W} / \mathrm{m} \mathrm{K}$ で、熱容量は $1500 \mathrm{KJ} / \mathrm{K}$ とした ${ }^{6)}$ 。土壤表面と外気側の総合熱伝達率は $23.0 \mathrm{~W} / \mathrm{m}^{2}$ • $\mathrm{K}$ とした。

\section{4 計算条件}

本計算では、家族構成は夫婦二人が生活するとし、室内の生活発 熱スケジュールは住宅における生活スケジュール発生プログラム8) から計算して表 5 のように仮定した。室内の家具などによる熱容量 は $4.55 \mathrm{MJ} / \mathrm{K}$ と計算した（住宅用標淮問題提案7) $4.5 \mathrm{Kcal} / \mathrm{m}^{3} \mathrm{~K}$ から）。

\section{4. 実測值による計算プログラムの検証}

実大実験住宅の 2001 年度および 2003 年度冬季実測データを用い て、計算プログラムの有効性を検証した。図 5 〜図 8 にその検証結 果の一部である 2003 年 12 月 2 日から 8 日間の集熱温度、室温、水 蓄熱体温度と床下空間温度の計算値と実測値を示す（気象データは 実測值を 1 時間毎に平均して使用した)。図 5 に外気温と日射量の推 移を示す。計算助走期間は 1 週間とし、この一週間の気象条件は 12 月 2 日と同じ条件として繰り返し計算を行った。

図 6 に集熱空気温度の実測値と計算值を示す。計算值は屋根の 集熱器出口温度であるのに対し、実測值は室内の集熱ダクト内 温度であるためファンが回っていない夜間や䁷天日には計算值 よりかなり高い温度になっている。それ以外の集熱時をみる と、計算值の最高温度が実測值より最大で $8{ }^{\circ} \mathrm{C}$ 程度高くなる時 もあるが、全体的にほぼ一致していることが分かる。

図 7、図 8 に室温、床下空気温度と水蓄熱体温度の実測値と計算 值を示す。全体的に誤差は少なく、ほぼ同じ変動をしていることが わかる。しかし、量った日と夜閒の明け方において水蓄熱体の計算 值が実測值より最大で $2{ }^{\circ} \mathrm{C}$ 近く低くなっている。これは水蓄放熱床 モデルでは根太が無く根太の部分まで水蓄熱体があると仮定して計 算を行っているため、実際より室温や床下空気温度の影響を受けや すくなっていることが原因と考えられる。しかし、システムの構成 要素の影響を検討するには充分な精度を持っていると判断し、以下 の検討を行った。
表 5 室内熱量発生スケジュール

\begin{tabular}{|l|l|c|c|c|c|c|c|c|}
\hline 時刻 & $0 \sim 5$ & 6 & 7 & 8 & 9 & $10 \sim 11$ & 12 & 13 \\
\hline (W) & 111.0 & 801.0 & 1066.5 & 345.6 & 377.1 & 177.0 & 265.5 & 705.5 \\
\hline \hline 時刻 & $14 \sim 16$ & 17 & 18 & 19 & 20 & 21 & 22 & 23 \\
\hline (W) & 177.0 & 345.5 & 436.0 & 1088.5 & 868.2 & 853.1 & 694.0 & 159.0 \\
\hline
\end{tabular}

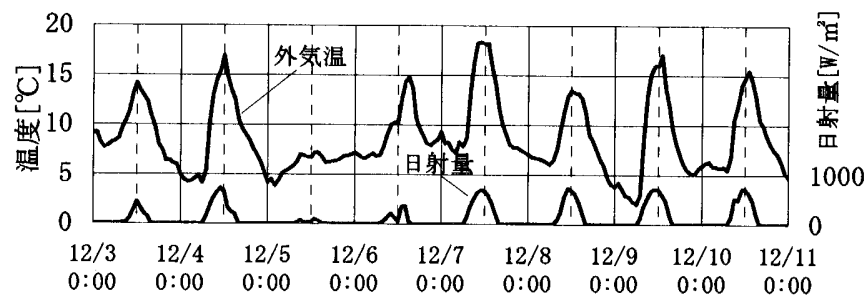

図 5 比較検討用期間の外気温と日射量 (2003 年)

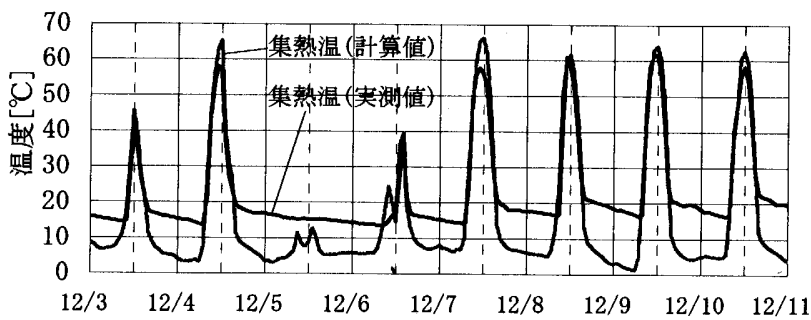

図 6 集熱空気温度の実測值と計算値

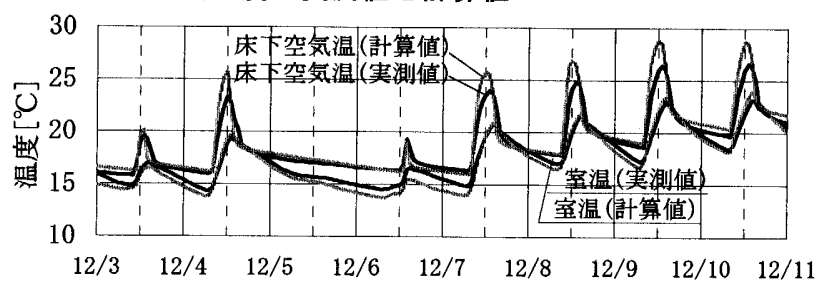

図 7 室温と床下空気温の実測值と計算值

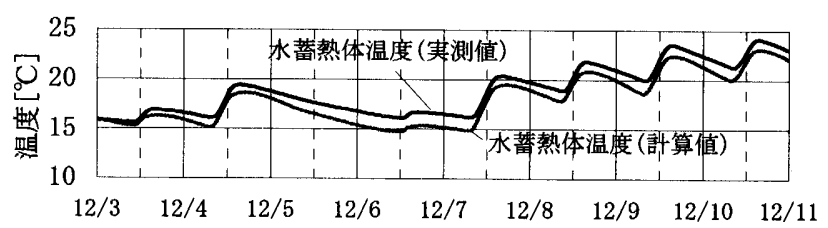

図 8 水蓄熱体の実測値と計算値

表 6 システム影響要素の水準

\begin{tabular}{|c|c|c|c|c|c|c|}
\hline 断熱材厚さ & $25 \mathrm{~mm}$ & $50 \mathrm{~mm}$ & $75 \mathrm{~mm}$ & $100 \mathrm{~mm}$ & $125 \mathrm{~mm}$ & $150 \mathrm{~mm}$ \\
\hline 換気回数 & 0.1 回 & 0.2 回 & 0.3 回 0.5 & 国 0.7 回 & 0.9 回 & 1.1回 \\
\hline 水蓄熱体熱容量 & OMJ & $5 \mathrm{MJ}$ & $10 \mathrm{MJ}$ & $15 \mathrm{NJ}$ & $20 \mathrm{MJ}$ & $25 \mathrm{MJ}$ \\
\hline 水蓄放熱床断熱材 & (1) & 無 & & & & \\
\hline 床の蓄熱体材料 & \multicolumn{2}{|c|}{ 水萻放熱床 } & \multicolumn{2}{|c|}{ ロンクリート床 } & \multicolumn{2}{|c|}{ 合板床 } \\
\hline 床下空間高さ & $1.3 \mathrm{~m}$ & $0.3 \mathrm{~m}$ & $0.1 \mathrm{~m}$ & & & \\
\hline 土間床スラブ厚さ & $0 \mathrm{~mm}$ & $50 \mathrm{~mm}$ & $100 \mathrm{~mm}$ & 150 min & & \\
\hline 土間床断熱材厚さ & $0 \mathrm{~mm}$ & $25 \mathrm{~mm}$ & $50 \mathrm{~mm}$ & $100 \min$ & $150 \mathrm{~mm}$ & \\
\hline 地 域 & 釧路 & 盛岡 & 仙台 & (⿻⿱㇒木⿲二丨匕刂 & 鹿児島 & 新潟市 \\
\hline 造 & 1: & $\mathrm{RC}$ 造 & *網挂 & 刀 & 漂準 & \\
\hline
\end{tabular}

\section{表 7 着衣量と代謝量の設定}

\begin{tabular}{|l|c|c|}
\hline & 23 時 5時 & 6時〜22時 \\
\hline 着衣量 (clo) & 3.0 & 1.2 \\
\hline 代謝量 (met) & 0.7 & 1.2 \\
\hline
\end{tabular}




\section{5．システム影響要素の検討結果}

表 6 に検討を行った影響要素と水準を示す (網措部分が標準)。冬 季の計算期間は 12 月〜 2 月までの 3 ヶとし、計算助走時間は 2 週 間とした。気象データはアメダスの標準年気象データを用いた。

評価は期間平均 PMV と期間積算快適時間率を用いて行った ${ }^{21)}$ 。期 間平均PMV は全計算期間におけるPMV の平均值であり、期間積算快 適時間率は計算期間の間に室内 PMV 值が $-1.0 \sim+1.0$ 間に入った時 間数が全時間に占める割合である。PMV を計算するに当たって相対 湿度は $50 \%$ 、室内風速は $0.15 \mathrm{~m} / \mathrm{s}$ と設定し、着衣量と代謝量は表 7 の ように設定した。

\section{1 建物の気密性と断熱性の影箘}

図 9 と図 10 に断熱性と気密性の計算結果を示す。断熱性は壁と屋 根の断熱材の厚さで、気密性は 1 時間の換気回数を用いて検討を 行った。計算結果から、断熱性と気密性がシステムの温熱環境に与 える影響は大きく、太陽熱を有効に利用する必要条件であることを 確認した。本モデル住宅においては、断熱材厚さが $100 \mathrm{~mm}$ を超える と、また換気回数は 0.3 回 $/ \mathrm{h}$ より少なくなると期間積算快適時間率 の変化は少ない。なお、図 10 で換気回数が 0.1 回/h の時が 0.2 回 / $\mathrm{h}$ 時より期間積算快適時間率が低いのは、PMV 值が +1.0 を超える時 間数が増えるため快適域に入る時間数が少なくなるからである。

\section{2 水蓄熱体熱容量の影響}

図 11 に水蓄放熱床の水蓄熱体熱容量が期間積算快適時間率に与 える影響について示す。まず、水蓄熱体がない0M J (合板床) の時と 水蓄熱体がある場合を比較すると、水蓄熱体を設置することにより 期間積算快適時間率を $20 \%$ 程度高めることができる。また、期間平 均PMV も約 0.2 高くなる。しかし、水蓄熱体がある場合を比較する と熱容量の違いによる効果はそんなに大きくない。そこで計算期間 における時間ごとの平均 P M V を計算し、分析を行った。その結果を 図 12 に示す。図より、明け方から集熱を行う直前までは熱容量が 少ないほどPMV 值も小さいが、集熱終了後から梁夜までは水蓄熱体 熱容量が少ないほど高くなっていることがわかる。これは、日中の 集熱中水蓄熱体熱容量が少ないほど水蓄熱体への蓄熱量は少なくな るが、その分室温が高くなることによって室内および床下コンク

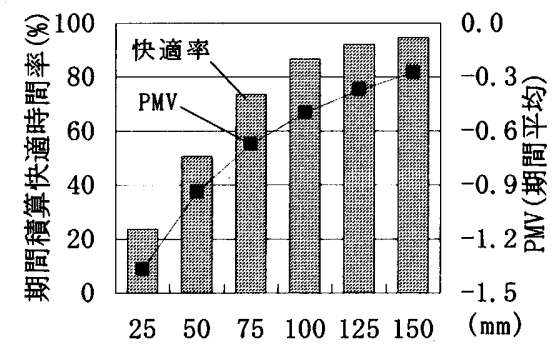

図 9 断熱性の影寷

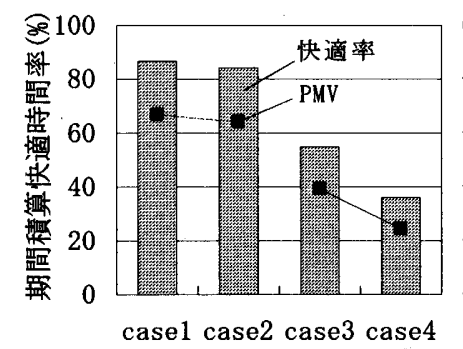

図 13 水蕃放熱休断熱材の影蔀
リートへの蓄熱量が増えるからであると考えられる。なお、2 3 時に PMV が急に高くなるのは着衣量と代謝量が変わるからである。

\section{3 水蓄放熱床の下側断熱材の影響}

図 13 に水蓄放熱床の下側断熱材の有無による計算結果を示す。 図で c a s e 1 は標準モデルにおける水蓄放熱床の下側断熱材がある場 合、c a s e 2 はない場合であるが、結果から見ると断熱材の効果はあ まり現れてない。これは標準モデルにおいては、土間床断熱材厚さ が $100 \mathrm{~mm}$ あり床下空間からの熱損失が少ないことが原因であると考 えられる。そこで、床下空間の熱損失が大きい場合の例として、土 間床断熱材が無い場合の水蓄放熱床の下側断熱材の有無による検討 を行ったのが case 3 と case 4 である。計算結果から、水蓄放熱床の 下側断熱材がある case 3 の快適時間率が断熱材が無い case4 より $20 \%$ 程度高く、期間平均 PMV も高くなっている。このように、床下空間 の熱損失が少ない時において水蓄放熱床の下側断熱材の効果は小さ いが、床下空間の熱損失が多い場合には断熱をした方が効率的であ ることがわかる。

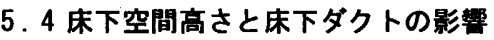

図 14 に床下空閒の高さと床下ダクトの有無による計算結果を示 す。床下空間の高さが低くなればなるほど期間積算快適時間率は高 くなるがその差は小さく、特に高さ $0.3 \mathrm{~m}$ と0.1 $\mathrm{m}$ においてはほとん どかわらない。また、床下ダクトの有無ついて比較すると床下ダク トを設置することにより期間積算快適時閒率を約 $5 \%$ 、期間平均 PMV を 0.2 近く高められることがわかる。

\section{5 土間床スラブの影響}

実大実験住宅の実測結果から、集熱を行う時の床下空間温度が高

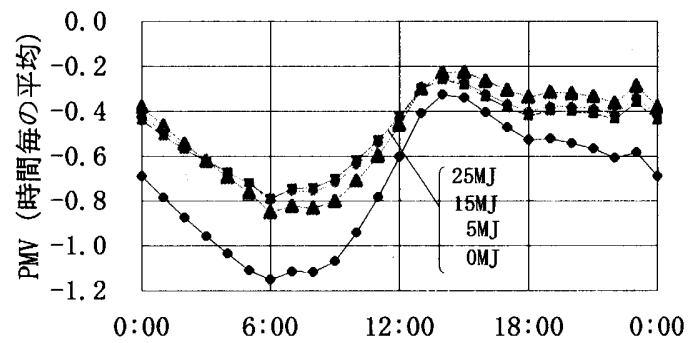

図 12 水蓄熱体熱容量の影響（時間毎の平均 PMV）

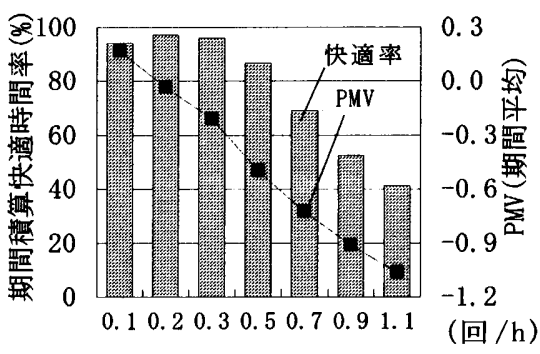

図 10 気密性の影幚

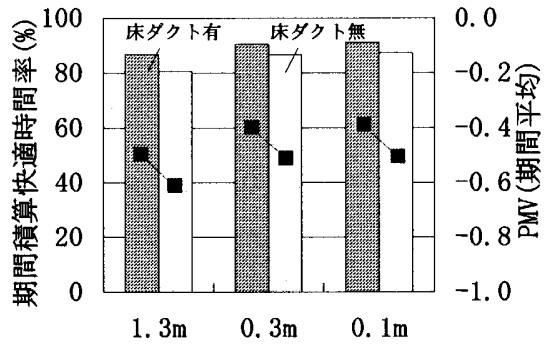

图 14 床下空間高さの影響

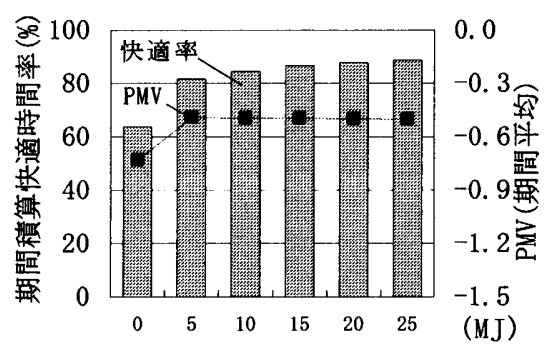

図 11 水蓄熱体熱容量の影䈏

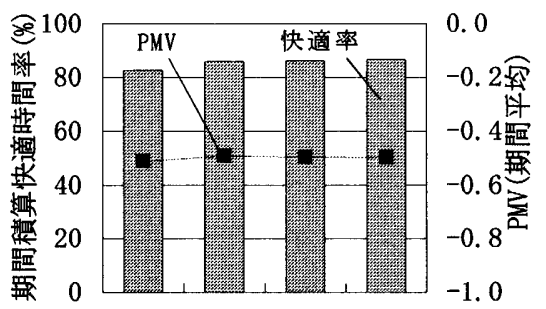

$0 \mathrm{~mm} \quad 50 \mathrm{~mm} \quad 100 \mathrm{~mm} \quad 150 \mathrm{~mm}$

図 15 土間床スラブ厚さの影䚝 


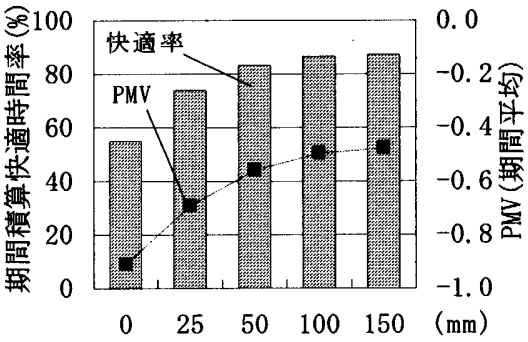

図 16 土間断熱材の影響

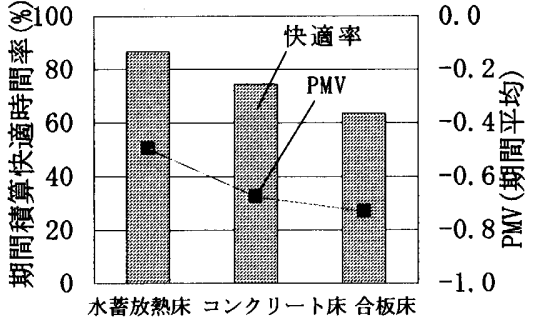

図 17 蕃放熱床の蓄熱体材料による検討

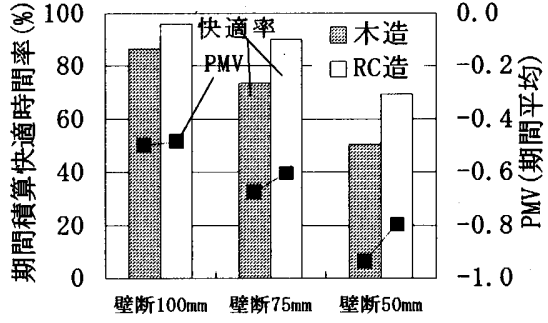

图 18 木造とRC 造による検討

くなることなどから土閒床スラブの蓄熱効果の影響を検討する必要 があると考えられる。図 15 にその結果を示す。しかし、計算結果 から見ると土間床スラブがある時はスラブがない時に比べ期間積算 快適時閒率が $5 \%$ 程度高くなっているものの、全体的に見て土閒床 スラブの効果は比較的に小さい。これは夜間において土間床スラブ の放熱量が少ないことと、直接室内に放熱しないのが原因であると 考えられる。従って、土間床スラブの蓄熱性を有効に利用するため には、夜間に循環用ファンを作動させるなどの何らかの工夫が必要 であると思われる。

\section{6 土間床断熱材の影響}

図 16 に土間床断熱材の厚さによる違いを示す。図から、土間床 断熱材の影響は大きく、断熱材が無い場合は標準モデル（100mm）に 比べて期間積算快適時間率が約 $30 \%$ 低く、期間平均PMV も 0.4 程度 低くなっている。また、土間床断熱材の厚さが $100 \mathrm{~mm}$ を超えると期 間積算快適時間率と期間平均 P M V 值の变化が小さくなっている。

\section{7 蓄放熱床の蓄熱体材料による険討}

図 17 に蓄熱体材料による検討結果を示す。コンクリート床は水 蓄放熱床と同じ熱容量のコンクリート（厚さ約 $12 \mathrm{~cm}$ ）が蓄熱体とし てあるとした。コンクリート床の非定常計算は後退差分法で行っ た。水蓄放熱床の場合がコンクリート床の場合と比べ期間積算快適 時間率が $20 \%$ 程度高く、期間平均 PMV 值も 0.2 以上高くなっている ことが分かった。これは同じ熱容量でも水蓄熱体の方が伝熱性が高 く、蓄熱量が多くなるためである。しかし、コンクリート床の場合 を合板床に比べると期間積算快適時間率が $20 \%$ 程度高く、期間平均 PMV も高くなっている。これらのことから、床部分に蓄熱体を設置

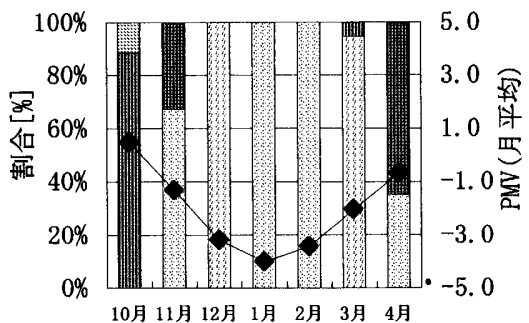

釧路

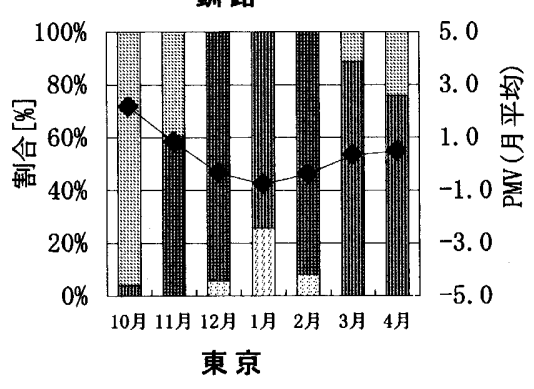

図 19 地域別の気象条件の違いによる検討

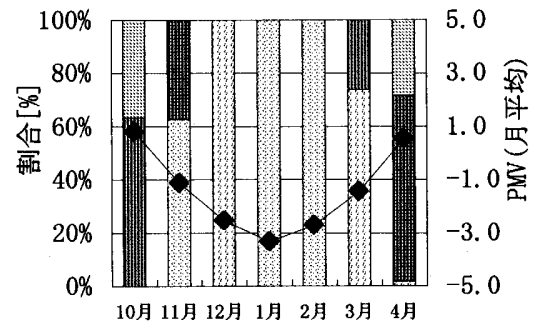

盛岡

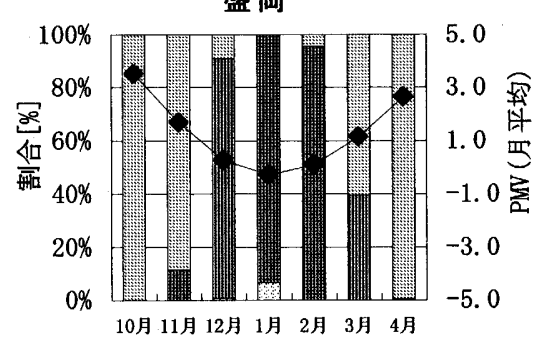

鹿坚島
寸ることは有効であり、ま
効果が高いことがわかる。

\section{8 木造とRC 造による検討}

室内の熱容量が大きい時の検討として、外断熱 R C 造との比較を 行った。図 18 にその計算結果を示す。RC 造のコンクリート厚さは、 住宅標淮問題 》)の提案を参考に $150 \mathrm{~mm}$ とした。また、熱損失性能に よる比較検討も行うために壁断熱材厚さが $100 \mathrm{~mm}, 75 \mathrm{~mm}$ と $25 \mathrm{~mm}$ の時 の計算も行った。全体的に RC 造の方が木造より効果がよく、また 断熱性が弱くなるにつれ R C 造の効果が高くなっていることがわ かった。

\section{9 地域別気象条件の違いによる検討}

地域別による気象条件の影響を検討寸るために I 地域から V 地域 までの中で比較的日射が多い釧路、盛岡、仙台、東京と当児島を選 択した。また、同じ地域における気象条件の影響も検討するため に、日射量が少なく東京と同じIV地域に入る新潟市についても計算 した。計算結果を図 19 に示す。計算結果から I 地域と II 地域の釧 路と盛岡において、外気温が低く、集熱温度が $30^{\circ} \mathrm{C}$ 以上になる時間 が少なかったため 12 月、 1 月と 2 月は期間積算快適時間率はほぼ 0 である。これから I 地域と II 地域においては断熱性を高めるなどの 更なる工夫が必要であると考えられる。これに比べて、III地域の仙 台とIV地域の東京では 1 月でも快適区閒に入る時間数が多く、太陽 熱だけでも快適域に入る時間が多かった。しかし、東京と同じIV地 域の新潟市については日射量が少ないため集熱温度が $30^{\circ} \mathrm{C}$ 以上にな る時間が少ない。本システムを建設する際は外気温だけではなく地 域の日射量も充分に考虑する必要があると考える。

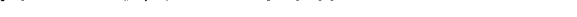

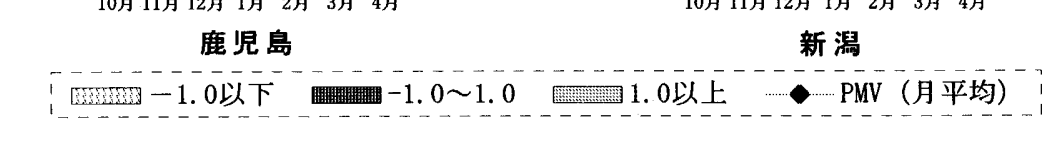

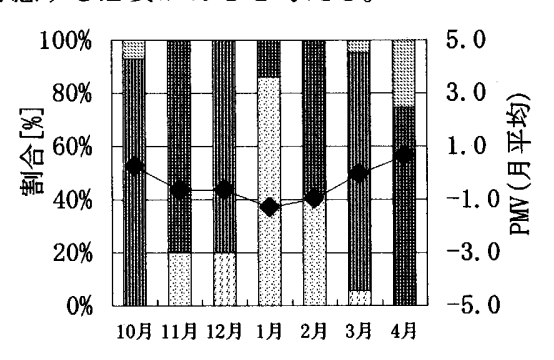

仙台

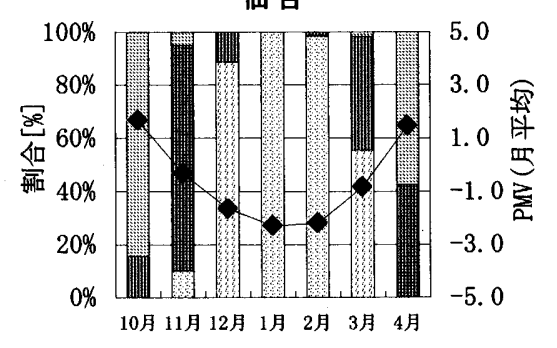

新潟 


\subsection{0 水蓄熱体の熱容量と熱負荷係数、集熱面積との関係}

本システムにおける適切な水蓄熱体の熱容量は主に建物の断熱 • 気密性と集熱性能により決まると考えられる。そこで、水蓄放熱床 の熱容量が熱損失係数と集熱面積とどのような関係にあるのかを把 握するために、本モデル住宅における水蓄熱容量と熱損失係数、集 熱面積との関係を調べる。ここでは、熱損失係数と集熱面積を 1 つ の変数にするために式（2）のように LCR 注2) として表現した。なお、 集熱面積は一般屋根部分とガラス集熱部分面積の合計とした。熱損 失係数は表 6 の断熱材厚さと換気回数を変更した場合の各ケースに ついて求めた ${ }^{8)}$ 。図 20 に水蓄熱体熱容量が $0 \mathrm{MJ} 、 5 \mathrm{MJ} 、 15 \mathrm{MJ} 、 25 \mathrm{MJ}$ の 時の計算結果を示す。まず0M J （合板床）の場合と水蓄熱容量があ る場合と比べると $1 /$ LCR が約 0.3 を超えると水蓄熱体があった方が 有効であり、また 1 / L C R が大きくなるにつれその差は大きくなる。 また、 $1 / \mathrm{LCR}$ が 0.4 以上では熱容量が大きい方が有利になる。しか し、1/LCR が 0.3 以下になると合板床の方が $15 \mathrm{MJ}$ と $25 \mathrm{MJ}$ の場合に比 べ時間率が高くなった。これは、熱損失が大きい時は集熱により蓄 熱せずに集熱時間帯の快適時間を多くした方が快適時間率が多くな るためと思われる。また、 $1 / \mathrm{LCR}$ が 0.4 より小さい時は $5 \mathrm{MJ}$ の場合が 4 つの中で最も快適時間率が高くなった。

\section{6. 結び}

本研究では、シミュレーションにより水蓄放熱床をもつ太陽熱床 暖房システムの性能に影響する要素について検討を行った。得られ た主な知見を以下に示す。

1. 断熱性と気密性がシステムの温熱環境に与える影響は大きく、 太陽熱を利用するに当たっての必須条件であることを確諗した。

2、床に水蓄熱体を設置することにより、期間積算快適時間率を水 蓄熱体がない合板床と比べて約 $20 \%$ 高めることができる。しかし、 水蓄熱体熱容量の増减による効果は小さく、本建物では $15 \mathrm{M} \mathrm{J}$ を超 えてからは変化が小さかった。

3. 水蓄放熱床の下側断熱材の効果は、床下空間の熱損失性能の影 響により異なる。例えば、床下空間の熱損失が少ない標準モデルで は断熱材の有無による効果はあまり見られなかった。一方、土閒床 断熱材が無い場合（床下空閒の熱損失が大きい場合）は、水蓄熱体 の下側断熱材があった場合の快適時間率がない場合に比べ約 $20 \%$ 高 くなり、期間平均 PMV も 0.2 近く高くなった。

4. 外断熱 RC 造との比較から、壁に熱容量を持たせることにより 期間積算快適時間率を $5 \%$ 程度高めることができ、その効果は断熱 性が弱くなるにつれ大きくなる。

5. 地域別による気象条件の検討から、寒冷地では断熱性能を高め るなど本システムを建設する際は外気温と日射量の影響を充分に考 慮する必要がある。

6. 本モデル住宅における水蓄熱体熱容量と断熱・気密性、集熱面 積との関係を把握することができた。ほとんどの場合において水蓄 熱体を設置したほうが有利であるが、1/LCR が 0.4 より大きい時は 熱容量が $15 \mathrm{M} \mathrm{J}$ 以上の方が、小さい時は $5 \mathrm{M} \mathrm{J}$ 程度の方が有利であっ た。また、1/LCR が 0.3 以下になると合板床の方が $15 \mathrm{MJ}$ と $25 \mathrm{MJ}$ の場 合に比べ時間率が若干高くなった。なお、これらは集熱器の効率特 性など様々な因子に影響されるので、さらに検討する必要があると 考えられる。

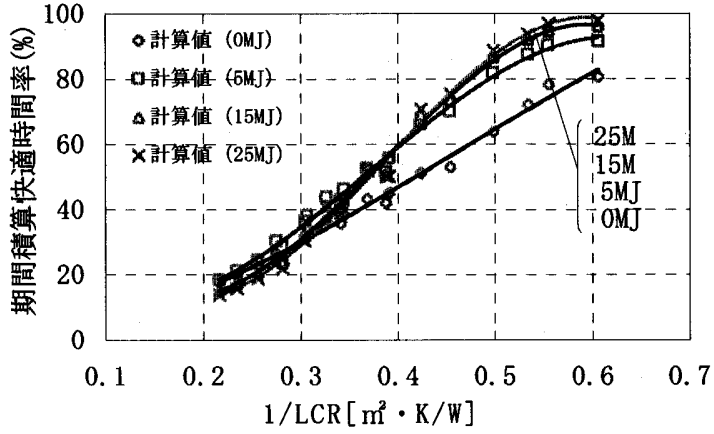

図 20 水蓄熱容量と熱負荷係数、集熱面皘との関係

$$
\begin{aligned}
& \mathrm{LCR}=\frac{\text { 熱負荷係数 }}{\text { 集熱面積 }} \quad\left[\mathrm{W} / \mathrm{m}^{2} \cdot \mathrm{K}\right] \\
& \text { 但し、熱負荷係数＝熱損失係数 } \times \text { 延心床面積 }
\end{aligned}
$$

注：1）本研究では、昼と夜の代謝量と着衣量の違いを直接考㦄して評価て きることと、日中の室温が高くなりすぎ不快になることを評価に入れるた めに、PMV を用いた期間快適時間率により評価を行った。

2）本システムの性能に大きく影響する要素は、水蓄熱体と建物の断熱・気 密性および集熱特性であると考えられる。そこで水蓄熱体以外の 2 つの変 数を 1 つの数值で表現できるものとして、パッシブソーラーヒーティング で使用されているLCR（Load Collector Ratio）法9）を用いて検討を行った。

[踈辞]

本研究の一部は、東京都立大学 21 世紀 C OE プログラム「巨大都市建筑ス トックの賦活・更新技術育成」の一環として行われたものである。

\section{[参考文献]}

1）咸哲俊・須永修通・堀祐治：水蓄放熱床をもつ太陽熱床暖房システムに 関する実駼研究 日本建築学会環境系論文集 第 572 号, p p. 39-45, 2003.10

2）中村健児 - 渡辺俊行 - 他 : 太陽熱利用空気集熱式床暖房住宅の設計指針 日本建筑学会計画系論文集 第 516 号, pp. 31-38, 1999.2

3) 渡辺俊行・他: 太陽熱利用空気集熱式床暖房住宅に関する調查研究 そ の $1 \sim$ その 6 日本建築学会大会学術講演梗概集 $1994 \sim 1996$ 、日本建築 学会九州支部研究報告集 1995,1996

4 ）宇田川光弘著 : パソコンによる空気調和計算法

5) 渡辺要著 : 建築計画原論 II

6) 松本真一：地下室の熱付加シミュレーションと環境設計 日本建築学会 環境工学委員会 熱環境小委員会第 33 回熱シンポジウム pp. 101-106, 2003. 12

7）宇田川光弘：標淮問題の提案 日本建築学会環境工学委員会熱分科会第 15 回熱シンポジウム pp. 23-33, 1985.9

8 ）住宅設伯委員会住宅のエネルギーシミュレーション小委員会 : 「住宅に おける生活スケジュールとエネルギー消費」空気調和・衛生工学会シンポ ジウム 2000.3

9)高間三郎 著: パッシブソーラーハウス入門 pp. 110-115

10 ) 李小平・奥宫正哉 : 太陽熱利用床暖房システムに関する研究 日本建築 学会計画系論文集 第 539 号, pp. 29-36, 2001.1

11) 石原修・他：パッシブエアサイクル住宅の温熱性能に関する研究 その 1 〜その 7 日本太陽エネルギー学会第 13 回研究発表会䜊演論文集 (1987) 日本太陽エネルギー学会・日本風カエネルギー势会・合同研究発表講演 論文集 $(1988,1989,1990)$

12）相良和伸・他：ソーラー八ウスの性能評価に関寸る研究 その1〜その 4 日本建築学会大会学術講演梗概集 1996,1997

13）趙雲・他：PCM 蓄熱材を利用したソーラーハウスの冬季実測調查 日本 建築学会大会学術講演梗概集 1997

14）伊藤直明、堀祐治他：蓄熱用アクアバッグを床面に持つ空気集熱・太陽 光発電併用のソーラーハウスの冬季熱性状に関する研究その 1 、その 2

日本建築学会大会講演梗概集 1999

15 須永修通・他：蓄放熱コンクリート床スラブをもつソーラーシステム TMU3 の実績 日本建築学会大会学術講演梗概集 pp. 553-554, 1981

16) 須永修通・他：太陽エネルギーを利用した水蓄熱放熱床暖房システムに 関する研究 その 1 、その 2 日本建築学会大会講演梗概集 2001

17) N. Sunaga, Y. Hori and Z. Xian, 'Thermal Performance of Solar Heating System with Water Floor', Proceedings of PLEA 2002, pp.297-301, 2002.7

18) Z. Xian, N. Sunaga and Y. Hori, 'Thermal Performance of Solar Heating System with Water Floor Part2, Study on the effect of Water Floor and energy-saving performance of this system', Proceedings of PLEA 2003, 2003,11 